\title{
En 39 år gammel mann med helårsrhinitt og akutt dyspné
}

\author{
En ung mann med helårsrhinitt plages gjentatte ganger av akutt \\ dyspné. Han får diagnosen astma, men til tross for behandling med \\ terbutalin og budesonid blir han over tid gradvis verre. Først to år etter \\ første dyspnéanfall kommer man frem til en løsning på problemene.
}

Se kommentar side 425 og kunnskapsprøve på www.tidsskriftet.no/quiz

En 39 år gammel mann oppsøkte legevakten med akutt tungpust som oppsto samme kveld mens han satt hjemme. Han hadde tidligere vært frisk bortsett fra at han det siste àret hadde hatt plagsom rhinitt. Det er beskrevet fra legevakten at han hadde både inspiratorisk og ekspiratorisk stridor. Det var ingen tegn til infeksjon. Han fikk behandling med forstøver med ukjent medikamenttilsetning og ble bedre. To uker senere fikk han på nytt anfall med dyspné, denne gangen mens han var på jobb. Han oppsøkte legevakten og ble igjen behandlet med forstøver. Han fikk i tillegg resept på terbutalin (Bricanyl). Legevaktlegen spurte ikke hva han arbeidet med.

Pasienten ble fulgt opp av fastlegen som i tillegg til terbutalin skrev ut resept på budesonid (Pulmicort). Fastlegen spurte heller ikke om arbeid, men sykmeldte han $i$ ti dager og henviste til medisinsk avdeling ved lokalsykehuset for vurdering. Spirometri der var upåfallende (i henhold til standard europeisk referansemateriale), med forsert vitalkapasitet (FVK; det maksimale volum luft ekspirert med maksimal kraft fra en posisjon av maksimal inspirasjon) på 4,0 l, Forsert ekspiratorisk volum (FEV ${ }_{1}$; det maksimale volum luft ekspirert under det første sekundet av FVKI på 3,2 l og ekspiratorisk toppstrømshastighet (PEF) på $540 \mathrm{l} / \mathrm{min}$. Lungenes diffusjonskapasitet for karbonmonoksid (TLCO) var normal, $11,4 \mathrm{mmol}$ $\mathrm{min} / \mathrm{kPa}$. Det var også normale funn ved auskultasjon over lungene.

Han ble fulgt opp med flere kontroller ved den medisinske avdelingen samme år. FEV falt til 2,8 I og luftstrømsvolumkurven fikk mer hengekøyefasong tydende på perifer obstruksjon, på tross av medisinering. Det ble gjort prikktesting for vanlig forekommende allergener, som viste ++ reaksjon for or, ellers negative funn. Total immunglobulin $E$ (lgE)nivå var lavt. Av ulike årsaker ble det ikke gjort test av bronkial reaktivitet (metakolintest). Han fikk diagnosen insipient astma.

Metakolintest er en test med høy sensitivitet for astma, men mindre god spesifisitet. Den utføres med inhalasjon av gradvis økende doser metakolin, som er en luftveisirriterende substans, for å se om det kan fremkalles bronkospasme. Positiv test indikerer bronkial hyperreaktivitet som er et uttrykk for en inflammatorisk prosess i luftveismucosa.

Lungespesialisten ved sykehuset spurte hva mannen arbeidet med og antydet at jobben kunne være årsak til hans plager. Legen anbefalte pasienten «å tenke gjennom om han kunne finne seg alternativt arbeid der han ikke var støv- og gasseksponert». Det ble også antydet at hans helårsrhinitt kunne være forårsaket av eksponering i arbeid.

Helårsrhinitt kan være relatert til arbeid og vil ved fortsatt eksponering ofte vise seg å være en forløper for astma. I denne situasjonen ville det vært naturlig for sykehuslegen å henvise pasienten til bedriftshelsetjenesten eller ev. til arbeidsmedisinsk avdeling for vurdering av behov for endringer $i$ videre arbeid og vurdering av mulige rettigheter for personer med yrkessykdom. Samtidig burde sykdommen ha vært meldt som mulig yrkessykdom til Arbeidstilsynet. Ifølge Arbeidsmiljøloven § 5-3 plikter leger å melde fra til Arbeidstilsynet ved antakelse om yrkessykdom.

Etter endt utredning ved den medisinske avdelingen gikk pasienten tilbake til sin fastlege og spurte hva han skulle gjøre med hensyn til videre arbeid. Fastlegen ba han vurdere à finne seg ny jobb. Dette syntes pasienten var vanskelig, og han fortsatte derfor i samme arbeid. Han følte at han gradvis ble tyngre $i$ pusten etter hvert som tiden gikk. Han tålte mindre anstrengelser både $i$ jobb og fritid. Pasienten fortsatte $i$ halvannet år før han til slutt - to år etter første dyspnéanfall - ble henvist til bedriftshelsetjenesten av fastlegen. Han ble derfra henvist til arbeidsmedisinsk avdeling uten videre utredning fra bedriftshelsetjenesten.

Pasienten har asiatisk opprinnelse og flyttet til Norge fem år før han fikk sitt første anfall med dyspné. Han hadde aldri røykt, og han kjente ikke til at noen i familien var atopikere. To år etter at han flyttet til Norge fikk han jobb som industrirørlegger ved et skipsverft. Han hadde altså jobbet der i tre år da han fikk sitt første dyspnéanfall. Arbeidsoppgavene var sveising og montering av rør. Sveisingen foregikk på ikke-rustfritt, til dels galvanisert, stål. I forbindelse med sveising brukte han sveiseskjerm og støvmaske som var en halvmaske med støvfilter. I periodene hvor han ikke sveiset selv, brukte han ikke bestandig støvmaske og han anga at han da kunne ha inhalert støv og røyk.

Det er flere faktorer å ta hensyn til ved bruk av støvmaske. Det er ikke lett å holde tilslutningen mellom maske og hud tett, og bare én dags skjeggstubb gjør at mye av lufta som inhaleres, kommer inn mellom huden og maskekanten, utenom filteret. Filtermasker som er lette å puste i og som derfor kjennes gode å arbeide med, er sjelden effektive. Under manuelt arbeid blir maskene fuktige innvendig og oppleves ubehagelige å ha på. Generelt vil vi anbefale bruk av trykkluftmaske i forbindelse med sveising. Dette er gjengs i mange sveisebedrifter i Norge i dag.

Han kunne ikke sikkert si at han ble verre $i$ pusten $i$ løpet av en arbeidsdag, men han hadde merket stor forbedring i pusten i forbindelse med ferier. På jobb tok han som regel to inhalasjoner med terbutalin daglig. De første par dagene av ferier hadde han fortsatt behov for terbutalin, men ikke deretter, så lenge ferien varte.

Ved undersøkelse på arbeidsmedisinsk avdeling var han plaget med hoste og betydelig rhinitt. Det var normale funn ved auskultasjon av lungene. Spirometri viste: FEV 3,2 I $186 \%$ av forventet verdi $i$ henhold til standard europeisk referansemateriale), FVK 3,8 ( (83\%). Spirometri etter terbutalininhalasjon viste ingen endring av betydning.

En bronkospasme vil kunne åpne seg etter inhalasjon av selektive beta-2-stimulatorer som terbutalin og salbutamol. Testen vil dermed kunne skille mellom astma og kronisk obstruktiv lungesykdom, ev. vil den kunne si noe om alvorlighetsgraden av astma. Om $\mathrm{FEV}_{1}$ øker med minst $12 \%$ og minimum $180 \mathrm{ml}$, tas det som tegn på at den bronkiale obstruksjonen er reversibel. En pasient som har mild eller ingen obstruktivitet på testtidspunktet, trenger ikke å vise reversibilitet for bronkodilator, hvilket kan forklare manglende effekt av terbutalin hos vår pasient. 


\section{Ramme 1}

\section{Klinisk praksis ved arbeidsrelatert astma}

1. Ta opp en arbeidsanamnese på alle voksne med astma. Personer som ikke lenger er i arbeid bør vurderes med henblikk på rettigheter til yrkesskadeerstatning.

2. Klarlegg pasientens egen oppfatning av arbeidsmiljøets betydning for utviklingen av sykdommen.

3. Dersom det er holdepunkter for arbeidsrelatert astma, skal melding sendes Arbeidstilsynet på eget skjema, 154b, med kopi til pasienten selv og eventuelt til NAV trygd (trygdekontoret). Pasienten bør ta kontakt med NAV og med nåværende, ev. siste, arbeidsgivers forsikringsselskap for å få vurdert om sykdommen kan godkjennes som yrkessykdom. Vi anbefaler også at pasienten tar kontakt med advokat. De første ti timer til advokathjelp dekkes vanligvis av arbeidsgivers forsikringsselskap.

4. Om pasienten har allergisk astma, vurder behovet for yrkesrettet attføring. Om sykdommen ikke er allergisk, diskuter med pasienten om hvilke yrkeshygieniske og organisatoriske tiltak som kan gjennomføres for å redusere eksponeringen for utløsende faktorer. Ikke glem uspesifikke faktorer som stress og dårlig inneklima.

5. Behovet for eksponeringsreduserende tiltak må meddeles en ansvarlig instans. Pasienten bør eventuelt få hjelp til det. $0 \mathrm{~m}$ bedriften har bedriftshelsetjeneste, er det rett instans. I motsatt fall kan arbeidsgiver, fagforening eller verneombud være til hjelp. Om pasienten ikke er fagorganisert eller bedriften er så liten (under ti ansatte) at det ikke finnes verneombud, kan man ev. henvende seg til Arbeidstilsynet eller pasienten kan henvises til en arbeidsmedisinsk avdeling (finnes ved alle tidligere regionsykehus og ved Sykehuset Telemark) for videre utredning og oppfølging.

6. Pasienten bør følges opp for å sikre at tiltakene blir gjennomført og har nødvendig effekt.

\section{Diagnose}

For å kunne vurdere om en sykdom kan karakteriseres som yrkessykdom, er det helt nødvendig med en sikker diagnose. Arbeidsmedisinsk avdeling ba derfor bedriftshelsetjenesten om å registrere toppstrømshastighet over en periode og påse at det var gjort en metakolintest ved lokalsykehuset.

Ved undersøkelse av lungespesialist ved lokalsykehuset hadde han imidlertid brukt budesonid inntil en uke før konsultasjonen på tross av instruksjon om å seponere tidli- gere. Grunnen til at han fortsatte med budesonid var at han fikk alvorlige symptomer da han sluttet. FEV, var ved denne undersøkelsen 2,2 l, en reduksjon på 1 l fra unders $\varnothing$ kelse to år før, og undersøkelsen tydet på obstruksjon også i de små luftveiene, slik at metakolintesten ble ansett som uaktuell. Det ble konkludert med at pasienten hadde sveiseutløst rhinitt og astma.

Bedriftshelsetjenesten fikk gjort toppstrømshastighetsregistrering av pasienten før og etter jobb og i forbindelse med ferie. Det ble gjort fire slike registreringer, tre $i$ jobbperioder og én etter ferie. Verdiene jobb var $550 \mathrm{l} / \mathrm{min}, 560 \mathrm{l} / \mathrm{min}$ og $570 \mathrm{l} / \mathrm{min}$. Etter ferie var verdien $620 \mathrm{l} / \mathrm{min}$.

Toppstrømshastighetsmåling er en metode for å påvise endringer i luftstrømsobstruksjon i relasjon til f.eks. arbeidsmessig eksponering. Målingen viser normalt døgnvariasjon og har sin laveste verdi om morgenen (ev. like etter oppvåkning). Fire registreringer er imidlertid for lite til å kunne dra slutninger om en eventuell sammenheng. Det er $i$ dag anbefalt at man gjør minst fire registreringer per dag over minst tre etterfølgende dager $\mathrm{i}$ jobb og tre etterfølgende dager fri fra jobb. Registreringene bør gjøres over minimum to jobbperioder og én friperiode (1). Det finnes hendige elektroniske instrumenter som lagrer måleresultatene og som pasientene selv kan administrere, forutsatt grundig instruksjon. $\AA$ tolke målingene er ikke helt enkelt, men f.eks. vil sprik på over $20 \%$ mellom høyeste og laveste døgnverdi tale for hyperreaktivitet. Et fritt tilgjengelig elektronisk program, OASYS, kan være til hjelp ved tolking av data. Om verdiene er lavere når personen er på arbeid enn når han er borte fra jobb, taler det for at arbeidsmessig eksponering har effekt.

Vi har meldt pasientens sykdom til Arbeidstilsynet med kopi til trygdekontoret. Han er bedt om å ta kontakt med sitt trygdekontor for å kreve å få sykdommen godkjent som yrkessykdom, og han skal også ta kontakt med arbeidsgivers forsikringsselskap for å søke om yrkesskadeerstatning etter lov om yrkesskadeforsikring. Han er for tiden sykmeldt, og det er opprettet kontakt med arbeidsgiver med henblikk på omplassering internt ved verftet.

\section{Diskusjon}

Arbeidsrelatert astma er en underrapportert tilstand som lett blir kronisk fordi den ofte ikke håndteres adekvat. Årlig meldes 100-200 tilfeller av arbeidsrelatert astma til Arbeidstilsynet (2). Dette antas å være en betydelig underrapportering. Mindre enn $5 \%$ av legene melder fra om antatt yrkessykdom. På bakgrunn av data fra Finland, som har spesielt god statistikk over arbeidsrelatert sykdom, skulle man vente at det årlig oppsto ca. 1000 nye tilfeller i Norge (3). Yrkesgruppene med høyest insidens av yrkesastma er aluminiumsarbeidere, bakere, billakkerere og sveisere (2). Vanlig praksis i dag er at pasienter med arbeidsrelatert astma behandles medikamentelt, mens pasientens arbeidsmiljø sjelden blir vurdert før sykdommen er i ferd med å gjøre videre arbeid umulig (2). Da er sykdommen ofte kronisk, og plagene vil gjerne vedvare selv om den arbeidsrelaterte eksponeringen opphører. Arbeidsrelatert astma omfatter både tilstander som er forårsaket av eksponeringer $\mathrm{i}$ arbeidsmiljøet (yrkesastma (occupational asthma)) og tilstander som forverres av forhold $\mathrm{i}$ arbeid (work aggravated asthma). I den første gruppen finner vi allergiske tilstander preget av eosinofil inflammasjon $\mathrm{i}$ luftveiene, tilstander som tradisjonelt er blitt antatt å utgjøre mer enn $90 \%$ av alle tilfeller av yrkesastma (4). De senere årene har man funnet holdepunkter for at kanskje så mye som $50 \%$ av tilfellene er utløst av eksponering for irritanter som gir ikke-allergisk astma med hovedsakelig nøytrofil inflammasjon i luftveiene (5).

Gruppen av astmatikere med sykdom som forverres i arbeid, er det lite kunnskap om (6). I en undersøkelse av sykmeldte astmatikere som vi gjorde i $2004-05$, fylte $70 \%$ av respondentene kriteriene for arbeidsrelatert astma (7). Kriteriene var positive svar på begge de to følgende spørsmål: «Har du noen gang fått luftveisplager (hoste, oppspytt, tungpust eller pipelyder i brystet) i forbindelse med arbeid?» og «Bedret luftveisplagene seg ved fravær fra arbeidet?». Av disse hadde $30 \%$ hatt astma som barn og $20 \%$ oppga at astmatiske plager ble forverret av uspesifikke stimuli som anstrengelse, stress og inneklimaforhold på arbeidsplassen.

\section{Tiltak}

Det finnes internasjonale retningslinjer for håndtering av allergisk yrkesastma. Disse går ut på at videre eksponering for utløsende agens må opphøre så snart som mulig $(8,9)$. F.eks. bør en baker med astma skifte arbeid, tilrettelegging på arbeidsplassen vil ikke kunne hindre forverring av sykdommen. For akutt irritantutløst astma (reactive airways dysfunction syndrome, RADS) går retningslinjene ut på å forhindre gjentakelse av utløsende eksponeringsforhold.

For astma som forverres av forhold på arbeidsplassen, finnes det ingen internasjonalt anerkjente retningslinjer, men etter vår oppfatning er det viktig med tett oppfølging og at arbeidsmiljøet også for disse blir lagt til rette med sikte på å forebygge utvikling av kronisk sykdom.

Pasienten har jobbet som sveiser på ikkerustfritt stål i flere år. Det har lenge vært kjent at sveising på rustfritt stål gir økt risiko for astma. Man har imidlertid også funnet holdepunkter for at sveisere generelt har økt risiko for å utvikle irritantutløst astma (10).

Norske retningslinjer for håndtering av arbeidsrelatert astma hos voksne er etter vår mening ikke tilfredsstillende i dag (11). De burde legge mer vekt på nødvendigheten av å 
skifte jobb for pasientene med allergisk sykdom og nødvendig tilrettelegging på arbeid for de med ikke-allergisk sykdom (ramme 1).

I dette tilfellet tok utredningen for lang tid. Ved nyoppstått astma hos en arbeidstaker er det en fordel å få gjort toppstrømshastighetsregistreringer og testing av bronkial reaktivitet før behandlingen starter. Spørsmålet om videre arbeid ble i dette tilfellet reist på et tidlig tidspunkt, men pasienten var ikke selv i stand til å gjøre noe med det. Derfor fortsatte han i eksponert arbeid med den følge at sykdommen forverret seg. Det å skifte arbeid er en alvorlig beslutning og de fleste trenger konkret veiledning og hjelp til å komme i kontakt med arbeidskraftsmyndighetene.

\author{
Jon Andsnes Berg* \\ jonandsnesberg@gmail.com \\ Håkon Lasse Leira \\ Unni Bratt \\ Siri Slåstad \\ Arbeidsmedisinsk avdeling \\ St. Olavs hospital \\ 7006 Trondheim
}

\author{
* Nåværende arbeidssted: \\ Glittreklinikken \\ 1488 Hakadal
}

Pasienten har gitt samtykke til at artikkelen blir publisert.

\section{Oppgitte interessekonflikter: Ingen}

Litteratur

1. Anees W, Gannon PF, Huggins V et al. Effect of peak expiratory flow data quantity on diagnostic sensitivity and specificity in occupational asthma. Eur Respir J 2004: 23: 730 -4.

2. Leira HL, Bratt U, Slåstad S. Notified cases of occupational asthma in Norway: exposure and consequences for health and income. Am J Ind Med 2005: 48: 359-64

3. Karjalainen A, Kurppa K, Martikainen R et al. Work is related to a substantial portion of adult-onset asthma incidence in the Finnish population. Am J Respir Crit Care Med 2001: 164: 565-8.

4. Newman Taylor AJ, Cullinan $P$ et al. BOHRF guidelines for occupational asthma. Thorax 2005; 60: $364-6$.

5. Douwes J, Gibson P, Pekkanen J et al. Noneosinophilic asthma: importance and possible mechanisms. Thorax 2002; 57: 643-8.
6. Malo J-L. Future advances in work-related asthma and the impact on occupational health. Occup Med 2005; 55: 606-11.

7. Leira HL, Berg JA, Bratt U et al. Mye arbeidsrelatert sykdom blant astmatikere. Tidsskr Nor Lægeforen 2006; 126: 2367-9.

8. Tarlo SM, Boulet L, Cartier A et al. Canadian Thor acic Society. Guidelines for occupational asthma. Can Respir J 1998; 5: 289-300.

9. Nicholson PJ, Cullinan P. Taylor AJ et al. Evidence based guidelines for the prevention, identification and management of occupational asthma. Occup Environ Health 2005; 62: 290-9.

10. Beach JR, Dennis JH, Avery AJ et al. An epidemiologic investigation of asthma in welders. Am J Respir Crit Care Med 1996; 154: 1394-400.

11. Norsk arbeidsmedisinsk forening - Kvalitetsutvalget. Arbeidsmedisinske veiledninger: Astma. www.nhi.no/amv (25.2.2008)

Manuskriptet ble mottatt 3.1. 2007 og godkjent 13.6. 2008. Medisinsk redaktør Erlend Hem.

\section{Kommentar}

\section{Når jobben er problemet}

I omkring $15 \%$ av nyoppståtte astmatilfeller hos voksne er eksponering i arbeidet vesentlig for utvikling av sykdommen (1). Korrekt diagnose er en forutsetning for å kunne igangsette adekvate tiltak når astma opptrer som følge av eksponering i arbeidet. I tilfeller som skyldes sensibilisering mot allergener $\mathrm{i}$ arbeid, vil tidlig intervensjon kunne bedre prognosen vesentlig. Dette forutsetter at legene kan identifisere tilstanden og evner å iverksette nødvendige tiltak. Går det mer enn et år etter symptomdebut før sanering av de aktuelle allergener, vil imidlertid mer enn halvparten av pasientene utvikle kronisk astma, selv om de tas ut av arbeidet (2).

Berg og medarbeidere viser et godt eksempel på de utfordringer som diagnostikk og oppfølging av nyoppstått astma medfører hos yrkesaktive voksne. Astmadiagnosen kan være vanskelig og bør prinsipielt være stilt på objektivt grunnlag så tidlig som mulig i forløpet. Målinger av ekspiratorisk toppstrømshastighet (PEF) i tidlig fase iverksatt av allmennlege eller bedriftslege mens pasienten fortsatt er i arbeid, kan gi gode holdepunkter for at arbeidsavhengig bronkokonstriksjon foreligger. Metoden skiller ikke absolutt mellom allergisk og annen type astma, for eksempel arbeidsforverret astma (3). I alt er ca. 250 forskjellige sensibiliserende stoffer beskrevet som årsak til allergisk astma i arbeid (4). Påvisning av sensibilisering kan kreve betydelig innsats. Innhenting av produktopplysninger fra be- driften kan være et nyttig hjelpemiddel for å oppspore allergener i arbeidsatmosfæren. Mistanke om sensibilisering kan bekreftes ved prikktest eller spesifikt IgE i serum, men få allergenekstrakter er kommersielt tilgjengelig. Spesielt ved småmolekylære allergener, slik som isocyanater, vil hudtester eller blodprøver som oftest ikke kunne gi diagnosen. Luftveisprovokasjon er referansemetoden, men denne er bare unntaksvis tilgjengelig i Norge (5). Atopi er risikofaktor for sensibilisering for høymolekylære allergener. Arbeidsbetinget rhinitt opptrer før astma $i$ mange tilfeller og diagnostisering av denne vil i slike tilfeller kunne føre til at adekvate tiltak blir satt inn før astma utvikles (6). På grunn av forsinket og lite presis diagnostikk vil beslutningsgrunnlaget i mange tilfeller være spinkelt.

Ved alle tilfeller av nyoppstått astma hos voksne må man overveie muligheten av sensibilisering i arbeidet som årsak til sykdommen. Ut fra dette kan effektiv intervensjon igangsettes i tidlig fase og kronisk astma forebygges. Påvisning av ett eneste tilfelle av allergisk yrkesastma gir grunnlag for primærforebyggende tiltak på arbeidsplassen som kan forhindre at nye arbeidstakere blir sensibilisert.

\section{Tor Brøvig Aasen}

tor.aasen@helse-bergen.no

Yrkesmedisinsk avdeling

Haukeland universitetssykehus

5021 Bergen
Oppgitte interessekonflikter: Ingen

\section{Litteratur}

1. Eagan TM, Gulsvik A, Eide GE et al. Occupational airborne exposure and the incidence of respiratory symptoms and asthma. Am J Respir Crit Care Med 2002; 166: 933-8

2. Rachiotis G, Savani R, Brant A et al. Outcome of occupational asthma after cessation of exposure: a systematic review. Thorax 2007; 62: 147-52.

3. Chiry S, Cartier A, Malo JL et al. Comparison of peak expiratory flow variability between workers with work-exacerbated asthma and occupational asthma. Chest 2007: 132: 483-8.

4. van Kampen V, Merget R, Baur X. Occupational airway sensitizers: an overview on the respective literature. Am J Ind Med 2000; 38: 164-218.

5. Vandenplas O, Malo JL. Inhalation challenges with agents causing occupational asthma. Eur Respir J 1997; 10: 2612-29.

6. Moscato G, Vandenplas O, Gerth van WR et al. Occupational rhinitis. Allergy 2008; 63: 969-80.

Manuskriptet ble mottatt 12.1. 2009 og godkjent 21.1. 2009. Medisinsk redaktør Erlend Hem. 